\title{
PENGARUH LAYANAN BIMBINGAN KELOMPOK DENGAN TEKNIK SOSIODRAMA TERHADAP PERCAYA DIRI PESERTA DIDIK KELAS XI MIPA SMA NEGERI 1 GUBUG
}

\author{
Aulia Muthia Khansa, Tri Suyati, Ismah \\ Program Studi Bimbingan dan Konseling, Universitas PGRI Semarang
}

\begin{tabular}{|c|c|}
\hline Informasi Artikel & ABSTRAK \\
\hline & \multirow{7}{*}{$\begin{array}{l}\text { Latarbelakang penelitian ini adalah banyaknya peserta didik yang } \\
\text { mempunyai kebiasaan sikap kurang percaya diri. Hasil data AKPD } \\
\text { menunjukkan siswa di SMAN } 1 \text { Gubug takut menjawab, enggan } \\
\text { memberikan pendapat, dan merasa minder tampil di depan kelas. } \\
\text { Tujuan dari penelitian ini untuk membuktikan pengaruh layanan } \\
\text { bimbingan kelompok dengan teknik sosiodrama terhadap sikap } \\
\text { percaya diri peserta didik kelas XII MIPA SMAN } 1 \text { Gubug. } \\
\text { Penelitian ini menggunakan metode kuantitatif dengan model pre- } \\
\text { test post-test control group design. Populasi dalam penelitian ini } \\
\text { adalah siswa kelas XI MIPA SMA Negeri } 1 \text { Gubug dengan jumlah } \\
245 \text { peserta didik. Sampel sebanyak } 36 \text { peserta didik diperoleh } \\
\text { dengan teknik cluster random sampling. Berdasarkan analisis data } \\
\text { penelitian uji hipotesis thitung }=4,217>\mathrm{t}_{\text {tabel }}=1,734 \text {. Hal tersebut } \\
\text { menunjukan bahwa layanan bimbingan kelompok dengan teknik } \\
\text { sosiodrama berpengaruh terhadap rasa percaya diri peserta didik. }\end{array}$} \\
\hline Diterima 10 November 2020 & \\
\hline Revisi 25 November 2020 & \\
\hline Disetujui 30 November 2020 & \\
\hline \multirow{4}{*}{$\begin{array}{l}\text { Penulis Korespondensi: } \\
\text { Ismah, } \\
\text { Email: } \\
\text { Ismarifai0503@gmail.com }\end{array}$} & \\
\hline & \\
\hline & \\
\hline & Kata kunci: Sosiodrama; percaya diri; bimbingan kelompok \\
\hline
\end{tabular}

\section{PENDAHULUAN}

Percaya diri merupakan suatu sikap atau perasaan yakin terhadap diri sendiri, dengan percaya diri individu tidak merasa cemas saat melakukan sesuatu dalam setiap tindakan. Kepercayaan diri berawal dari diri sendiri dan orang lain, karena percaya diri muncul akibat adanya dukungan dari orang lain untuk mengubah tidak percaya diri menjadi percaya diri. Dengan adanya percaya diri seseorang menjadi lebih yakin dalam menghadapi sesuatu. Bachtiar (2019) mengatakan bahwa percaya diri merupakan sebuah keberanian dalam diri individu untuk menghadapi sebuah tantangan dan memberi kesadaran bahwa belajar dari pengalaman jauh lebih penting daripada keberhasilan atau kegagalan. Purwanti (2018) percaya diri adalah keyakinan akan kemampuan diri sendiri terhadap lingkungan diri maupun situasi yang akan dihadapi. Memiliki sifat percaya diri 
sangat penting. Dengan percaya diri, peserta didik akan mampu mengambil tindakan yang sesuai dan tepat terhadap suatu masalah yang dihadapi dan mengaktualisasikan potensi yang dimiliki.

Bachtiar (2019); Primastuti \& Hapsari (2014) membagi faktor yang menyebabkan percaya diri menjadi dua factor, yaitu : (1) faktor internal yang berpengaruh di antaranya: konsep diri, harga diri, kondisi fisik, pengalaman hidup; dan (2) faktor eksternal meliputi pendidikan, pekerjaan, lingkungan. Dapat ditarik suatau kesimpulan bahwa untuk meningkatkan sikap percaya diri dibutuhkan keyakinan yang kuat dalam diri individu. Apabila individu tidak akan yakin dengan apa yang dikerjakan maka individu akan malu, minder, tidak berani untuk beraktualisasi diri. Puspitarini \& Faturachman (2017) menunjukkan hasil survey dari $43 \%$ dari total siswa SMA Negeri Palangkaraya menunjukan percaya diri yang rendah.

Kurangnya percaya diri pada peserta didik ternyata juga terjadi di SMAN 1 Gubug. Hasil AKPD (Angket Kebutuhan Peserta Didik) menunjukkan dari 281 siswa sebanyak $47,83 \%$ memiliki rasa percaya diri rendah. Dikuatkan dengan hasil observasi di SMAN 1 Gubug diperoleh data kurang percaya diri pada peserta didik. Kurangnya percaya diri terlihat ketika peserta didik tampil didepan kelas, mereka cenderung malu, takut salah, minder saat mengerjakan sesuatu, dan tidak mau menjawab soal dari guru. Selain itu, hasil wawancara dengan guru BK SMAN 1 Gubug ditemukan beberapa kasus, seperti: siswa masih takut dalam berpendapat di depan umum, merasa malu dan takut salah saat mengerjakan soal, malu bertanya saat tidak memahami, enggan menjawab pertanyaan dari guru, malu berkunjung ke ruang guru atau BK.

Merujuk rendahnya sikap percaya diri siswa di SMAN 1 Gubug maka perlu sebuah layanan BK yang dapat membantu meningkatkan sikap percaya diri. Salah satu layanan yang dapat digunakan untuk membantu siswa meningkatkan rasa percaya diri adalah bimbingan kelompok. Prayitno \& Erman (2008) menjelaskan layanan bimbingan kelompok merupakan layanan bimbingan yang diberikan dalam suasana kelompok. Bimbingan kelompok di sekolah merupakan kegiatan informasi kepada sekelompok peserta didik untuk membantu mereka menyusun rencana dan keputusan yang tepat. Hartinah (2009) menambahkan bahwa suasana kelompok dapat menjadi wahana dimana masing-masing anggota kelompok tersebut secara perseorangan dapat memanfaatkan informasi, tanggapan kepentinganya sesuai dengan kebutuhan dan problematika yang 
dihadapi. Bimbingan kelompok juga berfungsi untuk mencegah timbulnya masalah pada peserta didik dan mengembangkan potensi peserta didik.

Salah satu teknik dalam layanan bimbingan kelompok adalah teknik sosiodrama. Dengan teknik sosiodrama menurut Romlah (2001); Winkel (2006) sosiodrama adalah permainan perananan yang ditunjukan untuk memecahkan masalah sosial yang timbul dalam hubungan antar manusia. Konflik-konflik sosial yang diperankan tidak mendalam dan tidak menyangkut gangguan kepribadian, seperti: pertengkaran antar kelompok sebaya, perbedaan nilai individu dengan nilai lingkungan, perbedaan nilai antara anak dengan orangtua, dan sebagainya. Sosiodrama lebih merupakan kegiatan yang bertujuan untuk mendidik atau mendidik kembali daripada kegiatan penyembuhan. Kegiatan sosiodrama dapat dilaksanakan bila sebagian besar anggota kelompok menghadapi masalah sosial yang hampir sama, atau bila ingin melatih atau mengubah sikap-sikap tertentu. Oleh karena itu sosiodarama merupakan kegiatan yang dapat sangat cocok untuk membantu banyak orang muda dalam meningkatkan percaya dirinya. Pranoto (2016) menegaskan bahwa layanan bimbingan kelompok mampu pengentasan masalah percaya diri. Berdasarkan fakta dan acuan teori yang telah dipaparkan, maka penelitian ini bertujuan untuk mengetahui pengaruh layanan bimbingan kelompok dengan tehnik sosiodrama terhadap percaya diri peserta didik kelas XI MIPA SMAN 1 Gubug.

\section{METODE}

Metode penelitian yang akan digunakan adalah kuantitatif dengan jenis quasi eksperimen. Menurut Sugiyono (2016) penelitian quasi eksperimen ini merupakan pengembangan dan bentuk sederhana dari true eksperimental. Desain penelitian yang digunakan adalah pretest-posttest control group design. Adapun rancangan desain penelitian tergambar pada tabel 1 .

\section{Tabel 1 Desain Penelitian Pretest-Postest Control Group Design}

\begin{tabular}{|c|c|c|c|}
\hline Randon & Pretest & Treatment & Posttest \\
\hline $\mathrm{R}$ & $\mathrm{O}_{1}$ & $\mathrm{X}$ & $\mathrm{O}_{2}$ \\
\hline $\mathrm{R}$ & $\mathrm{O}_{3}$ & & $\mathrm{O}_{4}$ \\
\hline \multicolumn{4}{|c|}{ Keterangan: } \\
\hline $\mathrm{R}$ & \multicolumn{3}{|c|}{ : Randomisasi subjek } \\
\hline $\mathrm{O}_{1}$ & \multicolumn{3}{|c|}{ : Pretest pada kelompok eksperimen } \\
\hline $\mathrm{O}_{3}$ & \multicolumn{3}{|c|}{ : Pretest pada kelompok kontrol } \\
\hline$X$ & \multicolumn{3}{|l|}{ : Treatment } \\
\hline $\mathrm{O}_{2}$ & \multicolumn{3}{|c|}{ Posttest pada kelompok eksperimen } \\
\hline $\mathrm{O}_{4}$ & \multicolumn{3}{|c|}{ : Posttest pada kelompok kontrol } \\
\hline
\end{tabular}


Populasi yang digunakan dalam penelitian ini adalah siswa Kelas XI SMAN 1 Gubung. Sampel diambil secara random dengan melibatkan 20 siswa kelas XI SMAN 1 Gubung. Sampel dibagi menjadi dua bagian, 10 siswa masuk ke dalam kelompok eksperimen dan 10 siswa berikutnya menjadi kelompok kontrol.

Instrumen yang digunakan adalah kuesioner percaya diri yang terdiri dari 30 item dengan model jawaban menggunakan skala likert. Analisis data dilakukan untuk mengetahui pengaruh bimbingan kelompok terhadap sikap percaya diri dengan menggunakan t-test. Sebelum uji t-test dilakukan uji normalitas dan homogenitas untuk mengetahui kelayakan dan lolos syarat uji t-test.

\section{HASIL DAN BAHASAN}

Pendeskripsian data dilakukan untuk mempermudah dalam pemahaman terhadap variabel penelitian. Variabel bebas atau bimbingan kelompok dengan teknik sosiodrama dilambangkan huruf $\mathrm{X}$ dan variabel terikat atau mengembangkan rasa percaya diri dilambangkan dengan huruf Y. Dalam penelitian ini, menggunakan jenis penelitian quasi eksperimen dengan desain pre-test-post-test control group design, tujuan penelitian ini untuk mengetahui adakah pengaruh layanan bimbingan kelompok dengan teknik sosiodrama terhadap rasa percaya diri peserta didik pada kelompok eksperimen diberikan treatment dan kelompok kontrol tidak diberikan treatment.

Pre-test dilaksanakan dengan menyebarkan skala percaya diri untuk mengetahui tingkat awal rasa percaya diri peserta didik kelompok eksperimen dan kelompok kontrol pada kelas XI MIPA 4 yang sudah dipilih dengan teknik cluster random sampling. Peneliti dalam mengambil sampel untuk dijadikan kelompok eksperimen dan kelompok kontrol dengan cara membagikan sebuah formulir kesediaan peserta didik untuk mengikuti layanan bimbingan kelompok secara online/daring. Peserta didik yang bersedia mengikuti layanan bimbingan kelompok dengan teknik sosiodrama hanya terdapat 20 peserta didik dan sedangkan peserta didik yang lain tidak bersedia untuk mengikuti layanan bimbingan kelompok dengan teknik sosiodrama dengan alasan peserta didik yang tinggal di pedesaan kurang adanya sinyal yang mendukung karena pada kelas XI MIPA 4 masih banyak peserta didik yang berasal dari pedesaan, adapun peserta didik yang tidak ada waktu karena membantu keluarganya, beberapa peserta didik tidak memiliki ruang memori untuk menyimpan aplikasi yang berkapasitas besar untuk melaksanakan layanan bimbingan kelompok dan beberapa peserta didik tidak tertarik mengikuti kegiatan tersebut. Oleh 
karena itu sampel penelitian yang semula 36 peserta didik menjadi 20 peserta didik yang dibagi menjadi dua kelompok yaitu kelompok ekperimen dan kelompok kontrol. Sebelum menentukan dua kelompok tersebut peneliti menyebarkan intrumen kepada 20 peserta didik untuk dilakukan pretest sehingga mengetahui tinggi, sedang, rendahnya rasa percaya diri peserta didik kelas XI MIPA 4. Setelah dianalisis sehingga terdapat 10 kelompok eksperimen dan 10 kelompok kontrol.

Pelaksanaan pre-test dilakukan secara online dengan menggunakan media Google Form, peserta didik dapat mengisi skala percaya diri pada link yang sudah dibagikan melalui WhatsApp Group dirumah masing-masing dengan mudah. Kemudian dilanjutkan dengan pemberian treatment kepada kelompok eksperimen melalui layanan bimbingan kelompok dengan teknik sosiodrama sebanyak 5 (lima) kali.

Selanjutnya setelah diberikan treatment, diberikan post-test dengan menyebarkan skala percaya diri pada kelompok eksperimen maupun kelompok kontrol untuk melihat adakah pengaruh treatment yang diberikan dan mendapatkan hasil apakah sesuai dengan hipotesis yang ada atau tidak. Deskripsi data percaya diri peserta didik setalah dilakukan try out untuk menentukan kelas interval. Kategori penyusunan kelas disusun menjadi 4 kategori tergolong yaitu: sangat tinggi, tinggi, rendah, dan sangat rendah.

Berikut ini adalah deskripsi pelaksanaan perlakuan atau treatment baik kelompok kontrol maupun kelompok eksperimen. Treatment dilakukan dengan memberikan layanan bimbingan kelompok dengan teknik sosiodrama sebanyak lima kali pertemuan. Treatment diberikan kepada 10 peserta didik kelompok eksperimen secara rutin sesuai jadwal yang sudah ditentukan. Berikut ini deskripsi treatment yang dilakukan oleh peneliti:

Pertemuan pertama dilakukan pada hari Rabu, 14 Oktober 2020. Dengan durasi waktu 45 menit melalui aplikasi Zoom. Pertemuan pertama peserta didik yang mengikuti treatment masih merasa kebingungan, malu dan pasif. Pada pertemuan ini pemimpin kelompok cenderung lebih aktif menghidupkan suasana dan mengatur jalanya kegiatan agar tidak keluar dari topik pembahasan yang terkait dengan kemandirian (Mandiri dalam mengambil keputusan). Adapun yang dibahas yaitu pengertian kemandirian, bentukbentuk kemandirian, ciri-ciri pribadi mandiri. Pada saat pembahasan topik peserta didik terlihat kurang antusias dan merasa malu dalam menyampaikan pendapat-pendapatnya, seringkali juga peserta didik hanya terlihat diam. Hal ini juga dimungkinkan karena rasa percaya diri siswa yang rendah. Dalam memainkan drama peserta didik juga masih merasa 
malu, hal ini tampak ketika mereka bermain tidak sesuai karakter tokoh yang ada pada scenario. Selanjutnya tahap pengakhiran pemimpin kelompok mengevaluasi jalannya kegiatan bimbingan kelompok dan menyimpulkannya.

Pertemuan kedua dilaksanakan pada hari Jumat, 16 Oktober 2020. Pada pertemuan kedua peserta didik cukup antusias untuk mengikuti kegiatan bimbingan kelompok dengan teknik sosiodrama. Meskipun beberapa peserta didik antusias dalam mengikuti kegiatan ini, namun ada peserta didik yang masih saja diam dan tidak berani untuk mengungkapkan pendapatnya. Pada pertemuan kedua ini topik yang dibahas yaitu tentang optimis yang dibahas adalah tentang pengertian optimis, aspek-aspek optimis, manfaat sikap optimis, cara meningkatkan sikap optimis untuk menumbuhkan rasa percaya diri. Setelah pembahasan masalah kemudian dilakukan drama agar anggota kelompok lebih memahami dan mendalami peran agar hal-hal positif dalam naskah dapat diterapkan pada kehidupan nyata.

Pertemuan ketiga dilaksanakan pada hari Rabu, 21 Oktober 2020. Pada pertemuan kali ini anggota kelompok sudah terbiasa dengan formasinya. Terlihat juga anggota kelompok sudah mulai tenang dan tidak tegang seperti pada pertemuan-pertemuan sebelumnya. Pada topik ketiga pertemuan yang dibahas adalah tidak ragu-ragu yang pembahasannya meliputi pengertian keraguan, cara mengatasi keraguan, ciri-ciri peribadi yang tidak ragu-ragu. Pada saat pembahasan topik permasalahan pemimpin kelompok memberikan kesempatan kepada anggota kelompok untuk berani mengungkapkan pendapatnya dengan menunjuk dan mempersilahkan untuk berpendapat. Mesikpun dalam menjawab pertanyaan memerlukan banyak waktu yang sedikit lama karena peserta didik terlihat grogi dan takut jika jawabanya salah, namun dengan begitu mereka mampu untuk menjawabnya. Saat akan melakukan drama terkait dengan topik yang dibahas, beberapa anggota kelompok sudah lebih baik dalam memainkan perannya. Bahkan anggota kelompok sudah berani dalam mengajukan diri sebagai pemainnya. Selanjutnya pada tahap pengakhiran pemimpin kelompok tidak lupa melakukan evaluasi mengenai kegiatan yang sudah dilakukan dan meminta anggota kelompok untuk menyimpulakn mengenai kesimpulan topik yang dibahas

Pertemuan keempat dilaksanakan pada hari Kamis, 28 Oktober 2020. Pada pertemuan ini anggota kelompok sudah mulai terbiasa dan terlihat antusias dengan kegiatan layanan bimbingan kelompok. Topik permasalahan tentang konsep diri dengan 
topik pembahasannya yaitu pengetian konsep diri, jenis konsep diri dan faktor yang mempengaruhi konsep diri. Pada kesempatan kali ini saat pembahasan berlangsung, pemimpin kelompok dengan suka rela menwarkan kepada anggota kelompok untuk menyampaikan pendapatnya tanpa harus ditunjuk dan disuruh. Ternyata hampir semua anggota kelompok terlibat aktif dalam pelaksanaan layanan kali ini. Pembahasan semakin padat dan semakin seru, sehingga pembahasan melampaui waktu yang sudah ditentukan. Dengan itu layanan bimbingan kelompok dilanjutkan pertemuan selanjutnya, karena beberapa masih ada yang dibahas dan drama yang belum dilakukan sekaligus evaluasi dari topik yang dibahas.

Pertemuan kelima dilakukan pada hari Rabu, 4 November 2020. Pada pertemuan terakhir pembahasan yang dibahas yaitu topik pertemuan sebelumnya yaitu konsep diri. Anggota kelompok masih semangat dalam melakukan kegiatan, dan menjawab pertanyaan yang belum selesai saat pertemuan sebelumnya. Selanjutnya anggota kelompok memainkan peran sesuai naskah drama yang sudah disiapkan.

Pada tahap pengakhiran pemimpin kelompok memberikan kesimpulan dan evaluasi terkait dengan layanan bimbingan kelompok yang sudah dilakukan dan meminta anggota kelompok menyampaikan kesan dan pesan terkait dengan kegiatan yang sudah dilakukan selama ini.

Berikut merupakan perbandingan skor pretest dan posttest sikap percaya diri siswa pada kelompok eksperimen. Hal ini dimaksudkan untuk mengetahui perbedaan skor sebelum dan sesudah diberikan perlakuan.

Pretest dilakukan dengan menyebarkan skala percaya diri kepada kelompok eksperimen dan kelompok kontrol. Rekapitulasi hasil pretest yang telah diberikan pada peserta didik tercantum dalam tabel 2.

Berdasarkan hasil rekapitulasi pretest diperoleh skor pada kelompok eksperimen dengan 8 peserta didik dalam kategori rendah, 2 peserta didik dalam kategori sangat rendah, skor tertinggi 71, skor terendah 51, jumlah skor 629, dan dengan rata-rata 62,9. Jumlah skor tersebut dapat digolongkan dalam kategori tingkat percaya diri dengan presentase $100 \%$. 
Tabel 2

Rekapitulasi Hasil Pretest Kelompok Eksperimen

\begin{tabular}{|c|c|c|}
\hline $\begin{array}{c}\text { Kode } \\
\text { Responden }\end{array}$ & $\begin{array}{c}\text { Perolehan } \\
\text { Skor }\end{array}$ & Kategori \\
\hline Responden 1 & 71 & Rendah \\
\hline Responden 2 & 52 & Sangat Rendah \\
\hline Responden 3 & 51 & Sangat Rendah \\
\hline Responden 4 & 63 & Rendah \\
\hline Responden 5 & 60 & Rendah \\
\hline Responden 6 & 70 & Rendah \\
\hline Responden 7 & 69 & Rendah \\
\hline Responden 8 & 68 & Rendah \\
\hline Responden 9 & 58 & Rendah \\
\hline Responden 10 & 67 & Rendah \\
\hline Jumlah & \multicolumn{2}{|c|}{629} \\
\hline $\begin{array}{c}\text { Skor } \\
\text { Tertinggi }\end{array}$ & \multicolumn{2}{|c|}{71} \\
\hline $\begin{array}{c}\text { Skor } \\
\text { Terendah }\end{array}$ & \multicolumn{2}{|c|}{51} \\
\hline Rata-Rata & \multicolumn{2}{|c|}{62,9} \\
\hline
\end{tabular}

Adapun paparan rekapitulasi hasil pretest kelompok kontrol terdapat pada tabel 3. Berdasarkan hasil rekapitulasi pretest diperoleh skor pada kelompok kontrol dengan 7 peserta didik dalam kategori rendah, 3 peserta didik dalam kategori tinggi, skor tertinggi 77, skor terendah 54, jumlah skor 647, dan dengan rata-rata 64,7. Jumlah skor tersebut dapat digolongkan dalam kategori tingkat percaya diri dengan presentase $100 \%$.

Selanjutnya dipaparkan kategori distribusi frekuensi tingkat percaya diri pretest kelompok eksperimen pada tabel 4. Berdasarkan tabel 4 distribusi frekuensi pretest pada kelompok eksperimen menunjukkan 2 peserta didik masuk dalam interval 30-52 dengan kategori memiliki persentase 20\% dan pada interval 53-75 dengan kategori rendah terdapat 8 peserta didik dengan persentase $80 \%$.

Berdasarkan tabel 5 distribusi frekuensi pretest kelompok kontrol, pada interval 5375 dengan kategori rendah terdapat 7 peserta didik dengan persentase $70 \%$ dan pada interval 76-98 dengan kategori tinggi ada 3 peserta didik dengan persentase $30 \%$.

Selanjutnya, agar ketemu perbedaan antara sebelum dan sesudah perlakuan maka disajikan hasil rekapitulasi hasil posttest kelompok eksperimen dan kelompok kontrol. Rekapitulasi hasil postest kelompok eksperimen disajikan dalam tabel 6 dan rekapitulasi hasil postest kelompok eksperimen disajikan dalam tabel 7. 
Tabel 3

Rekapitulasi Hasil Pretest Kelompok Kontrol

\begin{tabular}{ccc}
\hline Kode Responden & Perolehan Skor & Kategori \\
\hline Responden 1 & 77 & Tinggi \\
\hline Responden 2 & 76 & Tinggi \\
\hline Responden 3 & 61 & Rendah \\
\hline Responden 4 & 63 & Rendah \\
\hline Responden 5 & 76 & Tinggi \\
\hline Responden 6 & 62 & Rendah \\
\hline Responden 7 & 60 & Rendah \\
\hline Responden 8 & 60 & Rendah \\
\hline Responden 9 & 58 & Rendah \\
\hline Responden 10 & 54 & Rendah \\
\hline Jumlah & \multicolumn{3}{|}{} \\
\hline Skor Tertinggi & 647 \\
\hline Skor Terendah & 77 \\
\hline Rata-Rata & 54 \\
\hline
\end{tabular}

Tabel 4

Distribusi Frekuensi Pretest Tingkat Percaya Diri (Eksperimen)

\begin{tabular}{|c|c|c|c|}
\hline Interval & Kategori & Frekuensi & Persentase \\
\hline $99-120$ & Sangat Tinggi & 0 & $0 \%$ \\
\hline $76-98$ & Tinggi & 0 & $0 \%$ \\
\hline $53-75$ & Rendah & 8 & $80 \%$ \\
\hline $30-52$ & Sangat Rendah & 2 & $20 \%$ \\
\hline \multicolumn{2}{|c|}{ Jumlah } & 10 & $100 \%$ \\
\hline
\end{tabular}

Tabel 5

Distribusi Frekuensi Pretest Tingkat Percaya Diri (Kontrol)

\begin{tabular}{|c|c|c|c|}
\hline Interval & Kategori & Frekuensi & Persentase \\
\hline $99-120$ & Sangat Tinggi & 0 & $0 \%$ \\
\hline $76-98$ & Tinggi & 3 & $30 \%$ \\
\hline $53-75$ & Rendah & 7 & $70 \%$ \\
\hline $30-52$ & Sangat Rendah & 0 & $0 \%$ \\
\hline \multicolumn{2}{|c|}{ Jumlah } & 10 & $100 \%$ \\
\hline
\end{tabular}

Berdasarkan tabel 6 distribusi frekuensi posttest pada kelompok eksperimen, terdapat 1 siswa dalam kategori rendah, 5 siswa dalam kategori tinggi, dan 4 siswa dalam kategori sangat tinggi. Tingkat kepercayaan diri rata-rata dari keseluruhan siswa adalah 88,7 yang termasuk dalam kategori tinggi. Adapun hasil rekapitulasi posttest diperoleh skor pada kelompok kontrol yang tercantum dalam tabel 7 diperoleh 5 siswa dalam kategori rendah, 5 siswa dalam kategori tinggi, dan rata-rata skor adalah 72,8 dengan kategori rendah. 
Adapun tabel kategori distribusi frekuensi posttest tingkat pemahaman percaya diri tercantum dalam tabel 8. Berdasarkan tabel distribusi frekuensi posttest pada kelompok eksperimen. pada interval 53-75 dengan kategori rendah ada 1 peserta didik dengan persentase $10 \%$, pada interval 76-98 dengan kategori tinggi ada 5 siswa dengan persentase 50\%, pada interval 99-120 dengan kategori sangat tinggi ada 4 peserta didik dengan presentase $40 \%$. Berdasarkan tabel 9 distribusi frekuensi posttest kelompok kontrol pada interval 53-75 dengan kategori rendah ada 5 peserta didik dengan persentase 50\% dan pada interval 76-98 dengan kategori tinggi ada 5 peserta didik dengan persentase $50 \%$.

Tabel 6

Rekapitulasi Hasil Postest Kelompok Eksperimen

\begin{tabular}{ccc}
\hline Kode Responden & Perolehan Skor & Kategori \\
\hline Responden 1 & 74 & Rendah \\
\hline Responden 2 & 103 & Sangat Tinggi \\
\hline Responden 3 & 82 & Tinggi \\
\hline Responden 4 & 99 & Sangat Tinggi \\
\hline Responden 5 & 81 & Tinggi \\
\hline Responden 6 & 85 & Tinggi \\
\hline Responden 7 & 86 & Tinggi \\
\hline Responden 8 & 99 & Sangat Tinggi \\
\hline Responden 9 & 78 & Tinggi \\
\hline Responden 10 & 100 & Sangat Tinggi \\
\hline Jumlah & 887 & \\
\hline Skor Tertinggi & 103 & \\
\hline Skor Terendah & 74 & \\
\hline Rata-Rata & 88,7 & \\
\hline
\end{tabular}

Tabel 7

Rekapitulasi Hasil Postest Kelompok Kontrol

\begin{tabular}{ccc}
\hline Kode Responden & Perolehan Skor & Kategori \\
\hline Responden 1 & 79 & Tinggi \\
\hline Responden 2 & 77 & Tinggi \\
\hline Responden 3 & 68 & Rendah \\
\hline Responden 4 & 75 & Tinggi \\
\hline Responden 5 & 77 & Rendah \\
\hline Responden 6 & 66 & Rendah \\
\hline Responden 7 & 65 & Rendah \\
\hline Responden 8 & 67 & Rendah \\
\hline Responden 9 & 76 & Tinggi \\
\hline Responden 10 & 78 & Tinggi \\
\hline Jumlah & 728 & \\
\hline Skor Tertinggi & 79 & \\
\hline Skor Terendah & 65 & \\
\hline Rata-Rata & 72,8 & \\
\hline
\end{tabular}




\section{Tabel 8}

Distribusi Frekuensi Posttest Tingkat Percaya Diri (Eksperimen)

\begin{tabular}{|c|c|c|c|}
\hline Interval & Kategori & Frekuensi & Persentase \\
\hline $99-120$ & Sangat Tinggi & 4 & $40 \%$ \\
\hline $76-98$ & Tinggi & 5 & $50 \%$ \\
\hline $53-75$ & Rendah & 1 & $10 \%$ \\
\hline $30-52$ & Sangat Rendah & 0 & $0 \%$ \\
\hline & Jumlah & 10 & $100 \%$ \\
\hline
\end{tabular}

Tabel 9

Distribusi Frekuensi Posttest Tingkat Percaya Diri (Kontrol)

\begin{tabular}{cccc}
\hline Interval & Kategori & Frekuensi & Persentase \\
\hline $99-120$ & Sangat Tinggi & 0 & $0 \%$ \\
\hline $76-98$ & Tinggi & 5 & $50 \%$ \\
\hline $53-75$ & Rendah & 5 & $50 \%$ \\
\hline $30-52$ & Sangat Rendah & 0 & $0 \%$ \\
\hline & Jumlah & 10 & $100 \%$ \\
\hline
\end{tabular}

Berdasarkan data posttest yang telah dilaksanakan dan diberikan sebuah treatment atau perlakuan dengan memberikan teknik sosiodrama terkait pemahaman atau gambaran rasa percaya diri peserta didik pada kelompok eksperimen sedangkan kelompok kontrol tidak mendapatkan treatment atau perlakuan tetapi tetap diberikan sebuah posttest. Hasil posttest yang telah diperoleh dari kelompok eksperimen memiliki tingkat interval 99-120 sebanyak 4 peserta didik dengan kategori sangat tinggi, interval 76-98 sebanyak 5 peserta didik dengan kategori tinggi, tingkat interval 53-75 sebanyak 1 peserta didik dengan kategori rendah, dengan presentase $100 \%$ yang mempunyai gambaran atau pemahaman terkait rasa percaya diri setelah diberikan sebuah treatment atau perlakuan yang berupa teknik sosiodrama sedangkan pada kelompok kontrol memiliki tingkat interval 76-98 sebanyak 5 peserta didik dengan kategori tinggi dan tingkat interval 53-75 sebanyak 5 peserta didik dengan kategori rendah dengan presentase $100 \%$ yang mempunyai gambaran atau pemahaman terkait rasa percaya diri tanpa diberikan perlakuan atau treatment.

Dari data posttest tingkat pemahaman percaya diri peserta didik dari kelompok eksperimen dan kelompok kontrol, yang sebelumnya kelompok eksperimen telah diberikan sebuah treatment atau perlakuan dengan memberikan sebuah teknik sosiodrama ternyata memberikan pengaruh positif dibandingkan kelompok kontrol tanpa perlakuan atau treatment. Di dalam sebuah kelompok eksperimen ini diberikan sebuah treatment 
atau perlakuan sebanyak lima kali. Sedangkan kelompok kontrol tidak diberikan sebuah treatment, alasannya apakah adanya sebuah perbedaan antara kelompok eksperimen dengan kelompok kontrol. Secara jelas, ternyata memang adanya perbedaan diantara kelompok eksperimen dengan kelompok kontrol tergambar pada gambar 1.

Berdasarkan gambar 1 grafik posttest pada kelompok eksperimen dan kelompok kontrol di atas dapat diketahui pada perbedaan hasil dalam kategori rendah kelompok eksperimen $10 \%$ dan kelompok kontrol 50\%, dalam kategori tinggi kelompok eksperimen $50 \%$ dan kelompok kontrol 50\%, dan dalam kategori sangat tinggi kelompok eksperimen $40 \%$ dan kelompok kontrol $0 \%$.

Hasil analisis tingkat pemahaman percaya diri sebelum diberikan treatment (pretest) pada kelompok eksperimen dan setelah diberikan treatment (posttest) terdapat perbedaan. Berdasarkan data yang dapat diperoleh hasil klasifikasi prosentase hasilnya setelah diberikan treatment berupa layanan bimbingan kelompok dengan teknik sosiodrama lebih tinggi dibandingkan dengan klasifikasi prosentase hasil sebelum diberikan treatment atau perlakuan.

Pada akhirnya hasil data setelah layanan bimbingan kelompok diberikan sebuah treatment memang memberikan sebuah peningkatan. Ini artinya bahwa layanan bimbingan kelompok dengan teknik sosiodrama dapat memberikan pengaruh yang positif untuk meningkatkan pemahaman atau gambaran terkait percaya diri. Dapat disimpulkan bahwa perolehan hasil posttest lebih tinggi dibandingkan hasil pretest. Agar mengetahui perbedaannya hasil selisih rata-rata pretest dan posttest, yang disajikan dalam bentuk grafik pada gambar 2. Berdasarkan grafik rata-rata hasil pretest dan posttest di atas diperoleh perbedaan hasil pretest pada kelompok eksperimen dengan rata-rata 62,9 dan kelompok kontrol dengan rata-rata 64,7 sedangkan pada hasil posttest pada kelompok eksperimen dengan rata-rata 88,7 dan kelompok kontrol dengan rata-rata 72,8.

Berdasarkan hasil pretest dan posttest terlihat ada perbedaan sebelum dan sesudah perlakuan pada kelompok eksperimen dan kelompok kontrol. Sebagai penguat untuk meyakini pengaruh intervensi/perlakuan terhadap tingkat percaya diri siswa maka dilakukan uji t. Adapun beberapa langkah sebelum diuji t ada proses pengujian normalitas dan homogenitas. 


\section{Gambar 1 \\ Grafik Posttest Percaya Diri}

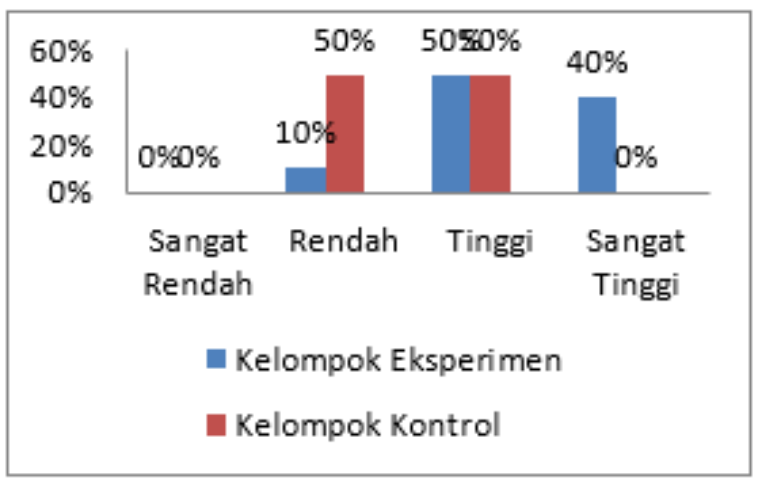

Uji normalitas distribusi sampel menggunakan uji liliefors dengan kriteria jika $\mathrm{L}_{\mathrm{o}} \leq$ $\mathrm{L}_{\text {tabel }}$ maka $\mathrm{H}_{\mathrm{o}}$ diterima. Artinya sampel berasal dari data yang berdistribusi normal. Jika $\mathrm{L}_{\mathrm{o}} \geq \mathrm{L}_{\text {tabel }}$ maka $\mathrm{H}_{\mathrm{o}}$ ditolak, artinya sampel berasal dari data yang berdistribusi tidak normal. Berdasarkan hasil perhitungan uji liliefors, diperoleh gambaran hasil yang tercantum dalam tabel 10 .

Berdasarkan uji normalitas awal pada tabel 10, diketahui bahwa $\mathrm{L}_{\mathrm{o}} \leq \mathrm{L}_{\text {tabel }}$ yaitu 0,111<0,258 pada kelompok eksperimen dan 0,226<0,258 pada kelompok kontrol, maka sampel dinyatakan berdistribusi normal. Berdasarkan tabel uji normalitas akhir, diketahui bahwa $\mathrm{L}_{0} \leq \mathrm{L}_{\text {tabel }}$ yaitu $0,201<0,258$ pada kelompok eksperimen dan $0,205<0,258$ pada kelompok kontrol, maka sampel dinyatakan berdistribusi normal. Data dihitung dengan microsoft office excel dan menggunakan liliefors.

Uji Homogenitas pada sampel yang digunakan adalah uji $\mathrm{F}$ dengan kriteria jika $\mathrm{F}_{\text {hitung }} \leq \mathrm{F}_{\text {tabel }}$ maka $\mathrm{H}_{\mathrm{o}}$ diterima. Artinya sampel berasal dari populasi yang homogen. Jika $F_{\text {hitung }} \geq \mathrm{F}_{\text {tabel }}$ maka artinya $\mathrm{H}_{\mathrm{o}}$ ditolak, artinya sampel berasal dari populasi yang tidak homogen.

Hasil uji homogenitas awal, diketahui bahwa $F_{\text {hitung }} \leq F_{\text {tabel }}$ yaitu $0,87<3,18$, maka $\mathrm{H}_{\mathrm{o}}$ diterima. Sehingga dapat disimpulkan bahwa sampel berasal dari populasi yang homogen. Dan jika $F_{\text {hitung }} \geq F_{\text {tabel }}$ maka $H_{o}$ ditolak, atau sampel tidak homogen. Adapun hasil uji homogenitas akhir, diketahui bahwa $F_{h i t u n g} \leq F_{\text {tabel }}$ yaitu $1,89<3,18$, maka $\mathrm{H}_{\mathrm{o}}$ diterima. Sehingga dapat disimpulkan bahwa sampel berasal dari populasi yang homogen. Dan jika $F_{\text {hitung }} \geq F_{\text {tabel }}$ maka $H_{o}$ ditolak, atau sampel tidak homogen. 


\section{Gambar 2}

Grafik Rata-rata Hasil Pretest dan Posttest

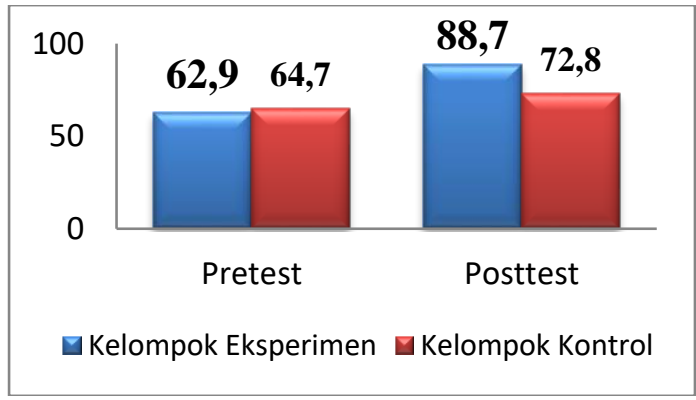

Tabel 10

Uji Normalitas Awal

\begin{tabular}{cccc}
\hline Kelompok & Lo $_{\mathbf{o}}$ & Ltabel & Kesimpulan \\
\hline Eksperimen & 0,111 & 0,258 & Berdistribusi Normal \\
\hline Kontrol & 0,226 & 0,258 & Berdistribusi Normal \\
\hline
\end{tabular}

Tabel 11

Uji Normalitas Akhir

\begin{tabular}{cccl}
\hline Kelompok & Lo $_{\mathbf{0}}$ & Ltabel & Kesimpulan \\
\hline Eksperimen & 0,201 & 0,258 & $\begin{array}{l}\text { Berdistribusi } \\
\text { Normal }\end{array}$ \\
\hline Kontrol & 0,205 & 0,258 & $\begin{array}{l}\text { Berdistribusi } \\
\text { Normal }\end{array}$ \\
\hline
\end{tabular}

Tabel 12

Analisis Data Post-test Rasa Percaya Diri (Kelompok Eksperimen dan Kelompok Kontrol)

\begin{tabular}{ccccc}
\hline No & $\mathbf{X}_{\mathbf{1}}$ & $\mathbf{X}_{\mathbf{2}}$ & $\mathbf{X}_{\mathbf{1}}{ }^{\mathbf{2}}$ & $\mathbf{X}_{\mathbf{2}}{ }^{\mathbf{2}}$ \\
\hline 1. & 74 & 79 & 5476 & 6241 \\
\hline 2. & 103 & 77 & 10609 & 5929 \\
\hline 3. & 82 & 68 & 6724 & 4624 \\
\hline 4. & 99 & 75 & 9801 & 5625 \\
\hline 5. & 81 & 77 & 6561 & 5929 \\
\hline 6. & 85 & 66 & 7225 & 4356 \\
\hline 7. & 86 & 65 & 7396 & 4225 \\
\hline 8. & 99 & 67 & 9801 & 4489 \\
\hline 9, & 78 & 76 & 6084 & 5776 \\
\hline 10. & 100 & 78 & 10000 & 6084 \\
\hline Jumlah & 887 & 728 & 79677 & 53278 \\
\hline Kode & $\sum \mathrm{X}_{1}$ & $\sum \mathrm{X}_{2}$ & $\sum \mathrm{X}_{1}{ }^{2}$ & $\sum \mathrm{X}_{2}{ }^{2}$ \\
\hline
\end{tabular}


Uji hipotesis pada penelitian ini adalah layanan bimbingan kelompok dengan teknik sosiodrama berpengaruh terhadap rasa percaya diri peserta didik kelas XI MIPA SMA Negeri 1 Gubug. Dalam rangka menguji hipotesis tersebut digunakan analisis $t$ test. Dengan dbN (20)-2 = 18 dengan taraf signifikan 5\% untuk $\mathrm{t}_{\text {tabel }}(18=1,734)=4,217$ maka $t_{\text {hitung }}>t_{\text {tabel }} 4,217>1,734$. Berdasarkan hasil perhitungan analisis $t$ test yang diperoleh $t_{\text {hitung }}$ sebesar 4,217 sementara $t_{\text {tabel }}$ dengan taraf siginifikan 5\% sebesar 1,734, karena $t_{\text {hitung }} t_{\text {tabel, }}$, 4,217>1,734 maka dapat disimpulkan bahwa "Ada pengaruh antara layanan bimbingan kelompok dengan teknik sosiodrama terhadap rasa percaya diri peserta didik kelas XI MIPA SMA N 1 Gubug."

Jadi layanan bimbingan kelompok dengan teknik sosiodrama dapat berpegaruh terhadap rasa percaya diri peserta didik kelas XI MIPA SMA Negeri 1 Gubug. Dengan demikian maka hipotesis kerja $\left(\mathrm{H}_{\mathrm{a}}\right)$ ada pengaruh layanan bimbingan kelompok dengan teknik sosiodrama terhadap pengembangan rasa percaya diri peserta didik kelas XI MIPA SMA N 1 Gubug.

\section{BAHASAN}

Berdasarkan hasil pengujian hipotesis disimpulkan bahwa layanan bimbingan kelompok dengan teknik sosiodrama dapat mempengaruhi rasa percaya diri peserta didik kelas XI MIPA SMAN 1 Gubug. Kondisi tingkat kepercayaan diri yang rendah ditunjukkan siswa dengan cenderung malu, takut salah, minder saat mengerjakan sesuatu, tidak mau menjawab soal dari guru, takut dalam berpendapat di depan umum, malu bertanya saat tidak memahami, dan malu berkunjung ke ruang guru atau BK. Hal ini seperti yang dijelaskan Dewi, D.M., dkk (2013) bahwa ciri-ciri kurangnya percaya diri siswa diantaranya gugup ketika mengerjakan sesuatu, kemampuan bersosialisasinya rendah, tidak percaya keapda kemampuannya sendiri, mudah menyerah atas kegagalan yang dihadapi, merasa dirinya mempunyai banyak kekurangan, dan suka menyendiri.

Kondisi percaya diri yang rendah sebenarnya memberikan dampak yang negatif terhadap perkembangan potensi siswa. Wahyuni (2014) mengatakan bahwa jika seseorang memiliki bekal percaya diri yang baik, maka individu akan dapat mengembangkan potensinya dengan bagus. Sebaliknya, jika seseorang memiliki percaya diri rendah, maka individu tersebut cenderung menutup diri, mudah frustasi ketika menghadapi kesulitan, canggung dalam menghadapi orang, dan sulit menerima realita dirinya. Dengan percaya 
diri saat maju di depan kelas, dapat meningkatkan keberanian siswa dalam menjawab pertanyaan. Selain itu dapat meningkatkan komunikasi dengan baik, memiliki ketegasan, mempunyai penampilan diri yang baik, dan mampu mengendalikan perasaan. Memiliki percaya diri yang tinggi dalam diri siswa dapat membantu mencapai prestasi dan hasil belajar yang lebih baik lagi. Dengan begitu akan terjadi proses perubahan dalam diri siswa bukan hanya pada hasil belajar tetapi juga pada perilaku dan sikap siswa, yaitu keberanian, keaktifan, dan aktualisasi diri siswa saat proses belajar mengajar.

Aristiani, R (2016) juga menambahkan bahwa percaya diri dapat dikembangkan melalui proses belajar dan pembelajaran sehari-hari serta menumbuhkan pembiasaan sikap berani dalam bersosialisasi baik di dalam kelas maupun luar kelas atau di lingkungan sekolah, maka dari itu percaya diri merupakan sifat pribadi yang harus ada pada peserta didik. Bercermin hal tersebut maka perlu sebuah kondisi untuk membiasakan agar siswa mampu untuk meningkatkan kepercayaan pada dirinya.

Bentuk upaya yang dapat dilakukan oleh konselor untuk meningkatkan kepercayaan diri adalah melalui bimbingan kelompok. Menurut Folastri \& Rangka (2016) bimbingan kelompok adalah suatu kegiatan yang diselenggarakan oleh tenangan professional bimbingan dan konseling terhadap suatu kelompok tertentu untuk mengembangkan kemampuan anggota kelompok kearah kemandirian dengan memanfaatkan dinamika kelompok. Dinamika kelompok yang baik akan melatih siswa untuk berani tampil, berkomunikasi, dan menunjukkan eksistensi diri. Semakin baik dinamika kelompok maka semakin mudah seseorang untuk bisa terbuka dan berkomunikasi dengan lancar. Hal ini sejalan dengan hasil penelitian Erlangga, E (2018); Setianingsih, E., dkk. (2014) yang mengatakan bahwa melalui bimbingan kelompok terjadi dinamika kelompok yang dapat melatih anggota kelompok untuk menjadi lebih terbuka dalam berkomunikasi. Keterbukaan dalam berkomunikasi akan lambat laun menjadikan sebuah kebiasaan yang baik bagi siswa untuk percaya diri dalam beraktualisasi diri. Syahrul, M (2012) menambahkan bahwa dinamika kelompok mengajarkan siswa untuk lebih terampil dalam proses penyesuaian diri dengan lingkungan. Dengan kata lain, siswa akan merasa mudah untuk menyesuaikan diri dengan variasi kondisi dan merasa percaya diri bergaul dengan kondisi yang dihadapi.

Salah satu teknik bimbingan kelompok yang dapat digunakan untuk menciptakan kondisi dinamika kelompok yang baik adalah sosiodarama. Donni (2017) menyatakan 
sosiodrama adalah kegiatan bermain peran untuk memecahkan berbagai masalah yang berkaitan dengan fenomena sosial, hubungan antar manusia seperti masalah kenakalan remaja, narkoba, gambaran keluarga otoriter, dan sebagainya. Sosiodrama digunakan untuk memberikan pemahaman dan penghayatan masalah sosial serta pengembangan kemampuan peserta didik untuk memecahkannya. Dalam hal ini, sosiodrama berfungsi sebagai sarana mealatih kepercayaan diri siswa, seperti: mengungkapkan pendapat, menjawab pertanyaan, bertanya dan kondisi aktualisasi lainnya. Sosiodrama dipercaya dapat meningkatkan kemampuan komunikasi anak. Hasil penelitian Widiawati, dkk. (2017) menyebutkan bahwa metode sosiodrama dapat meningkatkan kemampuan berbicara pada anak. Melalui permainan peran siswa diajarkan untuk mengekspresikan dirinya dalam sebuah alur cerita yang telah di susun oleh konselor. Alur cerita yang mengalir akan menstimulus siswa untuk berkomunikasi dengan anggota kelompok lainnya, sehingga secara tidak langsung siswa akan belajar bagaimana cara untuk berekspresi dan mengungkapkan kata. Seperti halnya ketika kondisi pembelajaran, tentu membutuhkan komunikasi untuk terjadi tranfer pengetahuan. Misalkan mengemukakan pendapat, bertanya, dan menyanggah hal yang kurang tepat. Tidak hanya itu, Erawan (2014) mengungkapkan bahwa melalui sosiodrama dapat meningkatkan kemampuan untuk berwawancara.

Merujuk pada kajian bimbingan kelompok dan sosiodrama dan hasil analisis data pretest-posttest skor rata-rata pada kelompok eksperimen menunjukan peningkatan setelah mendapat treatment. Selain itu, selama pemberian treatment, peserta didik sangat senang, antusias dan aktif dalam mengikuti kegiatan bimbingan kelompk dengan teknik sosiodrama. Azizah, N (2015) juga menguatkan bahwa sosiodrama adalah kegiatan dramatisasi yang menyenangkan sehingga siswa yang melaksanakan kegiatan akan merasa nyaman dan antusias untuk menerapkannya. Proses yang menyenangkan akan mempengaruhi siswa untuk menerapkan kondisi drama tersebut ke dalam lingkungan nyata. Dikuatkan hadil hasil evaluasi kegiatan sosiodrama ternyata peserta didik menerapkan dalam kehidupan sehari-hari khususnya dilingkungan sekolah. Artinya bahwa, terjadi perubahan kebiasaan peserta didik setelah mengikuti sosiodrama. Pasca kegiatan sosiodrama siswa menjadi lebih sopan dalam berbicara, lebih berani mengutarakan pendapatnya, menghargai diri sediri maupun orang lain, dan adanya perubahan tingkah laku dengan baik. Berdasarkan analisis data dan kajian teori, dapat 
disimpulkan bahwa layanan bimbingan kelompok dengan teknik sosiodrama berpengaruh dalam pengembangan percaya diri peserta didik kelas XI MIPA SMAN 1 Gubug.

\section{KESIMPULAN}

Layanan bimbingan kelompok dengan teknik sosiodrama berpengaruh terhadap percaya diri peserta didik kelas XI MIPA SMAN 1 Gubug. Sampel yang digunakan dalam penelitian ini diambil secara random sehingga tingkat kepercayaan diri praperlakuan berbeda satu dengan lainnya. Disarankan pada penelitian selanjutnya menggunakan metode purposive sampling agar peningkatan pada setiap individu lebih jelas dan dapat dilihat faktor yang berpengaruh terhadap perbedaan peningkatan skor. Selain itu, jenis kelamin pada penelitian ini diabaikan, sehingga saran untuk penelitian selanjutnya untuk lebih memperhatian jenis kelamin.

\section{DAFTAR RUJUKAN}

Aristiani, R. (2016). Meningkatkan Percaya Diri Siswa melalui Layanan Informasi Berbantu Audiovisual. Jurnal Konseling GUSJIGANG, 2(2), 182-189.

Azizah N. (2015). Peningkatan Kualitas Pembelajaran PKn melalui Metode Sosiodrama Berbantu Media Boneka Tangan pada Siswa kelas IV A SDN Tambakaji 03 Kota Semarang (Skripsi, Universitas Negeri Semarang).

Bachtiar, A. (2019). Tampil Beda dan Percaya Diri Itu Ada Seninya. Yogyakarta: Araska.

Dewi, D.M., Supriyo, Suharso. (2013). Kepercayaan Diri Ditinjau dari Pola Asuh Orangtua pada Siswa Kelas VII (Studi Kasus). IJGC, 2(4), 9-16.

Donni, J. (2017). Pengembangan Strategi dan Model Pembelajaran. Bandung: Pustaka Setia.

Erawan, D.G.B. (2014). Penggunaan Metode Sosiodrama untuk Meningkatkan Kemampuan Berwawancara dengan Berbagai Kalangan pada Siswa Kelas VIII SMP Mutiara Singaraja. Jurnal Santiaji Pendidikan, 4(1), 1-13.

Erlangga, E. (2018). Bimbingan Kelompok Meningkatkan Keterampilan Berkomunikasi Siswa. PSYMPATHIC: Jurnal Ilmiah Psikologi, 4(1), 149-156. https://doi.org/10.15575/psy.v4i1.1332.

Folastri \& Rangka. (2016). Prosedur Layanan Bimbingan dan Konseling Kelompok (Panduan Praktis dan Menyeluruh). Bandung: Mujahid Press.

Hartinah, S. (2009). Konsep Dasar Bimbingan Kelompok. Tegal: PT Refika Aditama.

Pranoto, H. (2016). Upaya Meningkatkan Percaya Diri Siswa Melalui Layanan Bimbingan Kelompok Di SMA Negeri 1 Sungkai Utara Lampung Utara. Jurnal Lentera Pendidikan LPPM UM Metro, 1(1), 100-111.

Prayitno \& Erman. (2008). Dasar-Dasar Bimbingan dan Konseling. Jakarta: Rineka Cipta.

Primastuti \& Hapsari. (2014). Kepercayaan Diri Mahasiswi Papua Ditinjau Dari Dukungan Teman Sebaya. Jurnal Psikodimensia, 13(1), 60-72.

Purwanti, L. N. (2018). Penguatan Pendidikan Karakter (PPK). Jakarta: Erlangga. 
Puspitarini, E \& Faturachman. (2017). Meningkatkan Kepercayaan Diri Siswa Menggunakan Bimbingan Kelompok dengan Teknik Sosiodrama Peserta Didik SMA N 4 Palangkaraya. Jurnal Bimbingan dan Konseling, 3(1), 5-7.

Romlah, T. (2001). Teori dan Praktek Bimbingan Kelompok. Malang: Penerbit Universitas Negeri Malang.

Setianingsih, E.S., Sutoyo, A., Purwanto, E. (2014). Pengembangan Model Bimbingan Kelompok Teknik Pemecahan Masalah untuk Meningkatkan Keterbukaan Diri Siswa. Jurnal Bimbingan Konseling, 3(2), 76-82.

Sugiyono. (2016). Metode Penelitian Kuantitatif, Kualitatif, dan R\&D. Bandung: Alfabeta.

Syahrul, M. (2015). Peningkatkan Penyesuaian Diri Siswa terhadap Lingkungan Sekolah melalui Layanan Bimbingan Kelompok di MTs. Darussalam Anrong Appaka. Journal of Educational Science and Technology (Est), 1(2), 46-60.

Wahyuni, S. (2014). Hubungan Antara Kepercayaan Diri Dengan Kecemasan Berbicara Di Depan Umum Pada Mahasiswa Psikologi. E-Journal Psikologi, 2(1), 50-64.

Widiawati, G.A.K.H., Suarni, N.K., Ujianti, P.R. (2017). Pengaruh Metode Sosiodrama Bermuatan Cerita Rakyat Terhadap Kemampuan Berbicara Pada Anak. E-Journal PAUD Undhiksa, 5(3), 252-262.

Winkel. (2006). Bimbingan Dan Konseling Di Instuti Pendidikan. Yogyakarta: Media Abadi. 